\title{
Beredskap og kontroll av maritim transport
}

\author{
Av Jan Georg Christophersen ${ }^{1}$
}

\begin{abstract}
The concept of state-corporate crime, which highlights joint government and private corporate action causing criminal harms, is a recent area of study with relatively few published cases. This paper focuses on state-corporate crime at the Norwegian government, specifically its failure to implement international conventions and agreements regarding shipping and port security against terrorism. It contributes to the study of state-corporate crime in three ways: (1) It adds a new case study to a field in which there are few published accounts; (2) it assesses the utility of an integrated theoretical framework for state-corporate crime and applies it to understanding harms at governmental, administrative and corporate levels; and (3) it demonstrates how the state's role in state-corporate crime can evolve from that of instigator to that of facilitator.
\end{abstract}

\section{Innledning}

Denne artikkelen tar for seg norske myndigheters manglende etterlevelse av egne inngåtte konvensjoner og avtaler om regulering og kontroll av sikkerhets- og terrorberedskap (»security«) $)^{2}$ i skipsfart og havner med særlig vekt på havneforhold. I undersøkelsen behandles også hvilke ulovlige og skadelige handlinger som blir resultatet når en eller flere politiske institusjoner søker å oppnå sine målsettinger gjennom samarbeid med selskaper (foretak) i næringslivet.

Skip og havner har svak beskyttelse mot terrorangrep. Angrepene kan rettes mot regimer gjennom sivile og militære mål for eksempel »Santa Maria« i 1961, "Achille Lauro« i 1985, »USS Cole« i 2000, »Limbourg« i 2002 og "Kartepe« i 2011. Skip i havn har også vært brukt som mål for angrep fra staters sikkerhetstjeneste for eksempel »Rainbow Warrior« som ble senket av fransk etterretning i havnen i Auckland 10. juli 1985. Slike former for »state crime« har vært gjenstand for forskning siden Chambliss (1989) introduserte begrepet »state-orga-

* Title in English: Security and preparedness in maritime transport - control in Norwegian sea ports 
nized crime« (se også Chambliss, Michalowski og Kramer, 2010; Cohen, 2002; Eskeland, 2011).

Skip som transporterer passasjerer eller gods kan kapres for å benyttes til frakt av farlig gods og derved utgjøre et »hensiktsmessig våpen «, eller angi retningen for et masseødeleggelsesvåpen brukt mot mennesker, et annet fartøy til sjøs eller mot havner som terrormål, i tillegg kommer de miljømessige konsekvensene. Ved å rette terrorhandlingene mot havner kan dette ramme verdenshandelen hardt, fordi sikre tilgjengelige havner og terminaler er en forutsetning for sjøtransport. Angrep mot én havn kan resultere i at også andre havner må stenge $\mathrm{i}$ den tiden det tar å klarere og evaluere sikkerhets- og terrorberedskap i den stat hvor angrepet fant sted, samt i nabostater og havner skipet anløp under reisen (Ross, 2000).

Den teoretiske rammen for dette arbeidet bygger på begrepet »state-corporate crime« som refererer til statens manglende etterlevelse av internasjonale og nasjonale reguleringer som et resultat av forholdet mellom statens politikk og praksis i kommersielle selskaper. Uttrykket state-corporate crime ble formulert av Kramer og Michalowski i 1990. Studier av denne form for lovbrudd er et område av kriminologien hvor det foreligger forholdsvis få sakstudier (Mathews og Kauzlarich, 2000). Tidlig på 1990-tallet var kriminologisk forskning rettet mot de maktsterkes lovbrudd $\mathrm{i}$ to atskilte underdisipliner: »corporate-crime « og »state crime« (Kramer, 1992, s. 214). For Kramer og Michalowski var dette et tema de ønsket nærmere innsikt i. De mente at skillet mellom de to nevnte formene for forskning rettet mot de maktsterke, hadde skygget for den kjensgjerning at staten og private selskaper er »funksjonelt avhengige« av hverandre. De fant det derfor ikke naturlig at avvikende handlinger gjennomført av den ene framsto uten noen assistanse fra den andre, enten det gjaldt oppdrag eller utelukkelse. (Kramer mfl. 2002, s. 270; se også Aulette og Michalowski, 1993, s. 173; Green og Ward, 2004, s. 28; Whyte, 2003, s. 579-80).

Kramer og Michalowski startet en ny retning for kriminologisk forskning hvor oppmerksomheten ble rettet mot »illegal or socially injurious actions« som kom fra »one or more institutions of political governance (pursuing) a goal in direct cooperation with one or more institution of economic production and distribution « (Kramer og Michalowski, 1991, s. 4; se også Kramer, 1990, s. 1; Kramer mfl., 2002, s. 269). Denne kriminologiske underart ble kalt state-corporate crime. State-corporate crime er slik det oppfattes av Kramer mfl. (2002) i en integrert teoretisk modell følgende: »based on the proposition that criminal or deviant behavior at the organizational level result from a coincidence of pressure for goal attainment, availability and perceived attractiveness of illegitimate means, and 
absence of effective social control« (Kramer mfl. 2002, s. 274). Denne definisjonen utgjør det teoretiske grunnlaget $\mathrm{i}$ dette arbeidet. $^{3}$

\section{Beskyttelse av den maritime transportkjeden}

World Trade Organization (WTO) opplyser at verdens produksjon har steget seks ganger siden 1950, mens eksporten kan multipliseres med en faktor på 18. Maritime aktiviteter er derfor avgjørende for verdensøkonomien, 80 prosent av all transitt går sjøveien.

De forente nasjoner (FNs) International Maritime Organzation (IMO) har vedtatt konvensjoner og den European Union (EU) har gjort vedtak om innføring av direktiver for å beskytte den maritime transportkjeden. Beslutningene konsentrerer seg om sikring av skip og havneinstallasjoner. Dette var grunnen til, i kjølvannet av terrorangrepet den 11. september 2001, at USA oppfordret IMO om å vurdere et generelt arrangement som kunne utgjøre et internasjonalt instrument for å oppdage og forebygge ulovlige eller ondsinnede handlinger som truer skip, deres mannskaper, passasjerer og last, og også (en ny idé) havneinstallasjoner, som representerer kontaktpunktet mellom land og skip.

IMO avsluttet arbeidet 12. desember 2002 ved godkjenning av et tillegg til Safety of Life at Sea Convention (SOLAS) (1974/1988) om maritime tiltak rettet mot sikkerhets- og terrorberedskap for skip, havner og myndighetsorganer, med ikrafttreden i 2004. Et nytt kapittel XI-2, kalt »Spesial Measures to Reinforce Maritime Security« som førte til utformingen av International Ship and Port Facilities Securit Code, (ISPS) Code. Koden etablerer et internasjonalt rammeverk for samarbeid mellom styresmakter, forvaltning, skipsfart og havneoperatører, for å oppdage og beskytte mot trusselen mot skipsfart og havner. Forebyggende tiltak ble satt i verk og gjelder for passasjerskip og lasteskip i internasjonal fart større enn 500 brutto tonn, for flyttbare boreplattformer og havneinstallasjoner som betjener slike skip. Tiltakene beskrevet i Del A i koden er obligatoriske, mens Del B er anbefalinger.

I den hensikt å minimalisere utsattheten har IMO og International Labour Organisation (ILO) utformet et utvalg praktiske direktiver som retter seg mot sikkerhets- og terrorberedskap i havner i den hensikt å oppfylle Resolusjon 8 i SOLAS konferansen. Dette initiativet utfyller ISPS-koden ved å utvide spørsmålet om sikkerhets- og terrorberedskap til også å omfatte »havnesonen«. I juni 2003 resulterte dette i ILO-vedtak av konvensjon 185 om havners identitetsdokumentasjon, hvor hensikten var forbedring av sikkerhets- og terrorberedskapen i denne sonen ved å gjennomføre sikker og verifiserbar personlig identifikasjon, som også skulle bidra til en felles orientering til spørsmålet om havnesikkerhet. Videre 
var intensjonen en forebyggende tilnærming som bygget på praksis og prinsippene i ISPS-koden. Ettersom initiativet ikke har lovs kraft, håper EU på at medlemsstatene definerer faste standarder i form av direktiv, styrt gjennom den felles innsats i IMO og ILO.

Maritim transport er grunnleggende for Europa, som handelsmessige er den viktigste part for to tredjedeler av all verdenshandel. Europa har ca. $1200 \mathrm{kom}-$ mersielle havner og håndterer mer enn 2 milliarder tonn ulike varer årlig. Den europeiske investeringen i maritim virksomhet, sammen med hoveddelen av verdensflåten som kontrolleres av europeiske skipseiere, førte i 2004 til vedtak i EU om regulering på europeisk nivå for å forsterke tiltakene som var vedtatt av IMO. Ved Rådets beslutning av 31. mars 2004 fikk direktiv (EC) No 725/2004 om tiltak for økt terrorberedskap på skip og i havnesoner, effekt for Norge gjennom medlemskap i Det europeiske økonomiske samarbeidsområde (EØS)-avtalen.

Nok et EU direktiv 2005/65/CE fra parlamentet og rådet, datert 26. oktober 2005, hvor intensjonen var utvidelse og styrking av den eksisterende kontrollen i havner og på terminaler til også å gjelde hele »havnesonen«. Havnesonen omfatter tilstøtende sårbare område av maritime havner. Mot slutten av det tjuende århundre ble maritime havner integrert som en del av en mye større enhet: transportkjeden. Svarene på behovene i markedene og den teknologiske utviklingen, var at havner ikke lenger bare var et sted hvor skip lastet og losset $i$ en industriell og kommersiell sone. Havnene var blitt viktige integrerte transportsentra og logistikkplattformer for internasjonal handel. Effektivitetsmessig er havner ett av leddene i logistikkjeden, hvor den ene delen ligger på land den andre er maritim. Gjennomstrømning i havner blir vurdert etter konkurransemessige kriterier hvor kvaliteten på hele transportkjeden tas i betraktning. En terrorhandlig rettet mot en landkomponent, vil forårsake en omgående nedgradering av en havns renommé, og gradvis kompromittere havnen.

Ved underskrift og ratifisering av internasjonale normer har Norge som en del av en global tilnærming til maritim sikkerhets- og terrorberedskap, med uvanlig hurtighet, harmonisert normene og innført dem i nasjonal lovgivning som for eksempel Lov-2007-02-16-9 Lov om skipssikkerhet (Skipssikkerhetsloven) som trådte i kraft 14. mars 2008. Denne lovens kapittel 6 omhandler bestemmelser som skal sikre skip mot terrorhandlinger. Lovgivningen baserer seg på IMOs regelverk, den internasjonale norm for sikkerhetsstyring og drift av skip og hindring av forurensning International Safety Management (ISM Code). Videre bygger loven på ISPS-koden fra 2002, som ble vedtatt og inkorporert i SOLAS kapittel XI-2 og trådte i kraft 1. juli 2004. 
For havnenes del gjelder Lov-2009-04-17-19 Havne- og farvannsloven med tilhørende forskrifter. Havneloven er en rammelov som utfylles av sentrale forskrifter (Forskrift om sikring av havner og havneterminaler mot terrorhandlinger mv. av 2007-07-03-825). Den nasjonale havnestrukturen er fastsatt i Nasjonal transportplan (NTP) og består av fem utpekte, internasjonale havner, 32 stamhavner og resten betegnes lokale havner, fiskerihavner, fritidsbåthavner eller lignende. Kystverket er pålagt å føre tilsyn med at havnene oppfyller kravene i det internasjonale regleverket om sikkerhet $\mathrm{og}$ terrorberedskap om bord på skip og $\mathrm{i}$ havner og havneanlegg. Når det gjelder skipene i internasjonal trafikk ligger ansvaret hos Sjøfartsdirektoratet for å sikre at reguleringene blir fulgt.

\section{Datagrunnlag}

Empirien til dette arbeidet er i hovedsak innhentet på tre måter. For det første en litteraturgjennomgang. For det andre ved intervjuer og samtaler med personer som var involvert i ESAs inspeksjonsarbeidet tilknyttet havneadministrasjoner, offentlige ansatte, næringsdrivende i havnenæringen og befal om bord på skip som trafikkerer norske havner. Samt egne observasjoner i havner og terminaler og ombord i skip. Det styrker datagrunnlaget at antall involverte personer i ESAs inspeksjoner i inn- og utland var betydelig både i offentlige organer og private selskaper.

Korrespondanse mellom ESA og norske politiske myndigheter er unntatt offentlighet. ESA påberoper seg hjemmel i »Rules on access to documents « Article 4(1)a. Norske myndigheter har med hjemmel i Lov om rett til innsyn i dokument i offentleg verksemd (offentleglova § 14) også unntatt de samme dokumentene fra innsyn. Det er grunn til å tro at det foreligger tilstrekkelig grunnlag for beslutningen, særlig fordi dette dreier seg om rikets sikkerhet. Hovedregelen i offentlighetsloven er at dokumenter i saker som er under behandling hos myndighetene, skal være tilgjengelig for alle. Når det ikke er tilfelle i denne saken, svekkes det empiriske materialet ved at verifiseringen av informantenes opplysninger ikke kan gjennomføres ved innsyn i originaldokumenter, men må foregå ved sammenligning av informantenes uttalelser.

\section{Maritim sikkerhets- og terrorberedskap}

Det ligger utenfor rammene av et forskningsprosjekt å komme med anbefalinger med hensyn til reguleringsmåten. Derimot er det en forskningsmessig utfordring å identifisere og beskrive eksisterende alternativer, herunder mulige kombinasjoner av flere reguleringsmåter. Målsettingen i denne sammenheng må blant annet 
være å legge til rette for en grundig og nyansert avveining av de tiltak som settes inn for økt sikkerhets- og terrorberedskap i maritim transport.

Et stadig tilbakevendende spørsmål er betydningen av internasjonal regulering og forholdet til implementeringen av denne i nasjonal lovgivning og hvordan få det til å virke. Denne sakstudien kan være et eksempel på de vanskelighetene som myndigheter, forvaltning og næringsliv møter.

Som medlem av EØS er Norge underlagt de samme kontrollsystemer som i European Free Trade Association (EFTA) og denne institusjonens overvåkningsorgan EFTAs Surveillance Authority (ESA) ${ }^{4}$ som har som hovedoppgave å sørge for at regler og plikter i EØS avtalen blir fulgt. ${ }^{5}$ ESA kan på eget initiativ gjennomføre kontroll i medlemsstatene. Hensikten med direktiv 725/2004 er å sørge for iverksetting av sikkerhets- og terrorberedskap som beskytter skip og havneinstallasjoner mot internasjonale trusler om tilsiktede handlinger.

EU-kommisjonen ønsket å foreta inspeksjoner for å undersøke om reguleringene ble fulgt i norsk forvaltning, i havner og om bord på skip.

Informanter opplyser at ESA i 2008 gjennomførte seks inspeksjoner av implementeringen av EU-forordning 725/2004 i Norge. Inspeksjonene var i hovedsak rettet mot myndigheter med ansvar for maritim sikkerhets- og terrorberedskap. I tillegg ble det gjennomført fem inspeksjoner hvor hovedvekten ble lagt på implementering i havner og på terminaler, og noen tilfeller om bord på skip. I tillegg gjennomførte ESA to inspeksjoner av havner og havneanlegg i 2009. Ifølge informanter klassifiserte ESA sine funn som: (a) graverende/grovt avvik (b) manglende etterlevelse og (c) etterlevelse, men forbedring ønskelig. Kun de to førstnevnte kategoriene kan i de private selskapene karakteriseres som lovbrudd. I de offentlige kontrollorganene som avvik eller manglende etterlevelse av forskjellig slag. Det ble funnet manglende etterlevelse og avvik i alle kategoriene.

I forbindelse med forhold som ble avdekket gjennom ESAs inspeksjoner i norske havner er det særlig to som bør nevnes. For det første skillet mellom statlig tilrettelagt og statlig initiert avvik eller manglende etterlevelse. Siden statlig tilretteleggelse som kan føre til manglende etterlevelse, vanligvis består i unnlatelser framfor konkret utøvelse, er dette blant de former for statlig tilrettelegging for lovbrudd som har fått minst oppmerksomhet (Barak, 1991; Friedrich, 2010). Statlig initiert lovbrudd foreligger hvor private selskaper, i samarbeid med staten, deltar i organisasjonsmessig avvik etter oppdrag fra, eller ved stilltiende godkjenning av myndighetene (Kramer mfl., 2002, s. 271). Tilrettelagt avvik eller manglende etterlevelse på den annen side kan skje når statens ytre etater (kontrollorganer) mislykkes i å hindre avvikende forretningsvirksomhet, enten på grunn av underforstått eller direkte hemmelig forståelse mellom næringsdrivende og myn- 
digheter som holder fast ved at felles interesser vil bli skadelidende ved aggressive reguleringer (Kramer mfl. 2002, 271-272).

\section{Manglende praktisering av reguleringer i norske havner}

Informanter opplyser at på det tidspunkt ESAs inspeksjoner fant sted hadde politiske myndigheter foretatt implementering av reguleringene i norsk lov i henhold til normal praksis. Derved ble inspeksjonene rettet mot Kystverket og Sjøfartsdirektoratet som er kontrollorganene (ytre etat). Informanter opplyser at manglende kommunikasjonen mellom disse institusjonene var åpenbar. ESA fant lovbrudd i private selskaper, avvik og manglende etterlevelse i kontrollorganene. Men særlig ble det rettet alvorlig kritikk mot at utøvende myndigheter ikke hadde etablert og satt i drift et system for mottak, behandling og oppfølging av forhåndsmeldinger fra skip som skulle anløpe norsk havn. Dette var brudd på direktiv 725/2004 Artikkel 6, jf. SOLAS kapittel XI-2 regulering 9. Forholdene ble betraktet som graverende/grovt avvik. Det samme gjaldt for skip i internasjonal fergetrafikk, men da snakker vi om skip eid av private selskaper, altså lovbrudd.

I tillegg ble det avslørt manglende samsvar med en rekke andre bestemmelser i regulering 725/2004. Det gjaldt manglende etablering av et nasjonalt maritimt sikkerhetsprogram. Norske kontrollmyndigheter kunne ikke føre bevis for at delegering av kontrollmyndighet til Recognised Security Organisation (REO), i dette tilfellet klassifikasjonsselskaper, hvor det skal dokumenteres at slike organisasjoner fyller kravene til kompetanse i henhold til reguleringens bestemmelser. Videre ble det funnet manglende samsvar med forpliktelsene til å fastsette nivået for sikkerhets- og terrorberedskap for havner. I tillegg kom at myndighetene ikke hadde informert havneledelsen om de krav som gjaldt sikkerhetsplanen for de ulike sikkerhetsnivåene, inkludert at dette også omfatter Declaration of Security (DoS). ${ }^{6}$ Disse forholdene ble betraktet som manglende etterlevelse.

For å kunne si noe om substansen i myndighetenes avvik, påført skade og risiko som samfunnet ble utsatt for i perioden hvor reguleringene ikke ble fulgt må oppmerksomheten rettes mot mangler ved oppfølging av de nye reguleringene. I dette tilfelle fikk implementeringen av ny lovgivning ikke direkte virkning i statens ytre etater Kystverket og Sjøfartsdirektoratet. En grunn var at politiske myndigheter ikke hadde avklart og fordelt arbeidsoppgavene mellom kontrollorganene. Fordeling av oppgaver til ytre etater krever at politisk ledelse erkjenner risiko, kommuniserer holdninger for derved å skape sikkerhetskulturer i etatene som skal føre tilsyn. Kystveket og Sjøfartsdirektoratet har de senere år gjennomgått omfattende strukturelle endringer som kan ha svekket både evne- og gjennomføringsvilje. På tross av omfattende statlige økonomiske overføringer som følger av 
relokalisering, utskifting av personell og opplæringstiltak, ble det ikke investert tilstrekkelig $\mathrm{i}$ etablering av effektive og robuste systemer for å løse spørsmål knyttet til samfunnssikkerhet. Beredskapen i havnekontrollen har ikke vært tydelig og høyt nok prioritert, noe som framgår av dårlig samordning og få krav til beredskapsmål. Resultatet ble at ESA fant at kontrolletatene hadde begått graverende grove avvik.

Det tok lang tid før alle havner med anløp av skip i internasjonal fart fikk etablert terminaler atskilt fra allmenn ferdsel i havneområdene, hvor det kunne føres effektiv kontroll med personer og last og hvor internasjonal og innenlands skipsfart ble fysisk atskilt. Skadene dette førte til må vurderes ut fra den risiko dette utsatte samfunnet for i perioden med manglende etterlevelse. Næringsdrivende utsatte etableringen av sikringstiltak. Derved oppnådde man at de økonomiske utleggene ble redusert, utsatte etableringskostnader betyr regnskapsmessig inntjening, men også økt risiko og svekket samfunnssikkerhet. De næringsdrivendes hovedbegrunnelsen for manglende etterlevelse var at behovet for slike reguleringer ikke fantes fordi det ikke forelå reelle terrortrusler i norske havner. I tillegg ble det hevdet fra næringshold at reguleringene ville medføre urimelige økonomiske belastninger for brukerne av transporttjenestene og at samfunnet burde ta slike kostnader. I møtet med ny lovgivning og næringsdrivende med mangelfulle holdninger, sikkerhetskultur, læringsvilje og interesse for samarbeid, hvor det foreligger et avhengighetsforhold til statlig infrastruktur, oppsto det former for økonomiske lovbrudd. Lovbrudd i form av unnlatelser av å følge lovgivningen er vel kjent fra maritim næringsvirksomhet som økonomisk kriminalitet (Christophersen, 2009).

En vesentlig risiko ved en slik utvikling er at det kan ha en spredningseffekt havnene imellom. Informanter opplyser at det forekom manglende etterlevelse i havner langs hele kysten, beskyttelsestiltak ble forsinket og samfunnssikkerheten svekket før ESA påviste avvik og manglende etterlevelse i kontrollorganer og lovbrudd i havenæringer og skipsfart.

\section{Nasjonal gjennomføring av internasjonale regelverk}

Kulturelle og strukturelle forhold kan sies å være en delforklaring på at norske myndigheter av ulik politisk valør ofte er tidlig ute med underskrift og ratifiserting av internasjonale konvensjoner og avtaler, denne gangen av ISPS-koden og EU direktiv 725/2004. Deretter ble reguleringene implementert i norsk lovgivning uten forsinkelser. Derved var det politiske ansvaret tatt og rammene satt. Det som ikke var tatt stilling til var det arbeid Kystverket og Sjøfartsdirektoratet som ytre etater er pålagt i forhold til skip og havner. Spørsmålet blir derfor om Fiske- 
ri- og kystdepartementet (FKD) på en tilfredsstillende måte benyttet sin styringsplikt overfor de ytre etatene. Manglende oppfølging av at forvaltningen etterlever vilkårene i reguleringene kan skyldes strukturelle forhold som vil være en sak for Riksrevisjonen. Det framgår ikke av offentlig tilgjengelig informasjon om Riksrevisjonen hadde tilstrekkelige indikatorer for evaluering av departementenes arbeid i denne saken.

Dersom det politiske etablissementet ikke har innsett betydningen av samfunnssikkerhet og beredskap i maritim transporten vil det svekke statens legitimitet på dette feltet. Det er grunn til å peke på at den symbiose som staten, skipsfartsnæringen og havneindustrien lever i som ledd i transportkjeden kan føre til lovbrudd. Manglende iverksetting og kontroll av reguleringer fra myndighetenes side kan i selskapene oppfattes som en mulighet til å unngå investeringer og derved øke inntjeningen. Samtidig som mangelfull kontroll av næringsdrivende kan betraktes som offentlig godkjenning av avvik, altså former for ulovlig samarbeid og derved kan være en sak for Økokrim.

Her bør det understrekes at de mangler og avvik som framkom under ESAs inspeksjoner ikke er vanlige eller typisk for norsk forvaltning. Tiltak som skulle vært iverksatt tidlig i 2005, var så sent som medio 2009 fortsatt ikke formelt klarert. Blant de uavklarte spørsmål som framkom under inspeksjonene var om en eller flere etater skulle være ansvarlig for innsamling og analyse av forhåndsmeldinger fra skip. Dessuten manglet det drift av regime for mottak, analyse og oppfølging av skipsmeldinger. Disse forhold er de mest sentrale forebyggende tiltak i direktiv 725/2004. Når disse ikke var iverksatt ble mangelen vurdert som graverende/grovt avvik. Uklarhet om ansvarsfordelingen i kontrollorganene kan ses som en hovedårsak til avvik og mangler. En medvirkende årsak kan være at både Kystverket og Sjøfartsdirektoratet på denne tiden befant seg i en situasjon med omfattende strukturelle endringer som tok mye oppmerksomhet.

Mottak og analyse av forhåndsmeldinger fra skip er for skipsfarts- og havneindustrien det samme som Politiets sikkerhetstjeneste (PSTs) ${ }^{7}$ analyse av terrorfaren ellers i landet. Eller man kan se det som om Etterretningstjenesten ${ }^{8}$ ikke skulle motta og analysere informasjon som gjelder sivile og militære sikkerhetsspørsmål. Kystverket og Sjøfartsdirektoratet har det koordinerende og rådgivende ansvaret for all forhåndsinformasjon om skip som har til hensikt å anløpe norsk havn. Det er lite trolig at noen vil stille spørsmål ved viktigheten av sikkerhetsog terrorberedskap i sjøhavner etter erfaringene med terrorangrepet 22. juli 2011. Det er like usannsynlig som om det ble stilt spørsmål ved om det skal være kontroll av passasjerer og last i lufthaver. Et eksempel kan belyse situasjonen. I 22. juli- kommisjonen (NOU 2012:14) legges avgjørende vekt på at en gate i Oslo 
sentrum ikke var stengt for å hindre at biler kunne ta seg fram til sentrale bygninger i Regjeringskvartalet. Alle involverte myndigheter inkludert PST og Etjenesten var kjent med risikoen, men tilstrekkelige beredskapstiltak ble ikke satt $\mathrm{i}$ verk. Kritikken i ettertid har vært hard. Det er derfor vanskelig å forestille seg at norske havner ikke skal ha krav på vern mot terrorangrep gjennom å motta og analysere forhåndsmeldinger fra skip og eventuelt stenge havner for anløp av risikotrafikk.

Spørsmål om mottak av sikkerhetsinformasjon ble behandlet i St.meld. nr. 22 (2007-2008) Samfunnssikkerhet samvirke og samordning. Her omtales sektoransvaret som det overordnede prinsipp i alt nasjonalt sikkerhets- og beredskapsarbeid. Kystverket er mottaker av alle meldinger fra skip i utenriks fart som skal anløpe norsk havn. Allerede i 2004 ble det bestemt at en av Kystverkets trafikksentraler skulle være teknisk mottaker av skipsmeldinger i henhold til skipsrapporteringssystemet $\mathrm{SafeSeaNet}^{9}$ regimet. Det virket derfor naturlig å betrakte Kystverket som det formelle organ som burde ha oppgaven med å motta forhåndsmeldinger fra skip i henhold til art. 6 i direktiv 725/2004 (jf. regulering 9 , pkt. 2 i SOLAS-konvensjonens kap. XI-2). Dessuten er det også i samsvar med Kystverkets ansvar å ta vare på Norges interesser som kyststat. Som en konsekvens det ansvar Kystverket har for norske havner og havneterminaler, ble det fra brukerhold ansett som naturlig at også vurdering og analyse av informasjonen, samt avgjørelser om det er åpenbare grunner til å anta at skipet ikke fyller vilkårene i SOLAS burde ligge hos Kystverket. Derved kunne viktige oppgaver samles i en etat, noe som ville gjøre tjenesten mer brukervennlig og bidra til større effektivitet fra det tidspunkt meldingen mottas til eventuell aksjon mot skipet besluttes og iverksettes. Men Kystverket manglet fortsatt medio 2009 formell myndighet og kompetanse til å ivareta disse funksjonene.

Kystverket har ansvar for etableringen av åpne kontaktkanaler til Sjøfartsdirektoratet/Skipskontrollen, politi, Forsvaret og Kystvakten. Ved behov for iverksetting av eventuelle kontrolltiltak og sanksjoner mot skip skal det kunne rekvireres assistanse fra et eller flere av ovenfor nevnte myndighetsorganer. I denne sammenheng er det grunn til å nevne Forsvarets informasjonsdelingssystem Costal Operations and Surveillance System (COSS) som ble etablert i 1995 for å bidra til effektiv håndheving av anløpsforskriften. Systemet er besluttet innlemmet i en tverrfaglig utveksling av trusselvurderinger, en forutsetning for effektive maritime sikkerhetsoperasjoner. Imidlertid kom politiske myndigheter etter hvert til at det ville være hensiktsmessig å dele Kystverkets ansvar med Sjøfartsdirektoratet. En del av begrunnelsen var at i de tilfeller hvor forhåndsmeldingen avdekker mistanke om åpenbare grunner til å anta at skipet ikke oppfyller vilkårene i SOLAS 
kap. XI-2 og ISPS-kodens del A, skal Sjøfartsdirektoratet varsles som rett instans. Motiveringen var videre at direktoratet har ansvaret for å gjennomføre inspeksjoner og bortvise fartøyer.

Før ESA innledet sitt inspeksjonsarbeid var norske politiske myndigheter av den oppfatning at de hadde etablert et nasjonalt sikkerhetsprogram gjennom en rekke delegeringer av ansvar. Under inspeksjonene ble det konstatert at myndighetene ikke hadde forsikret seg om at delegering av kontrollmyndighet til klassifikasjonsselskaper medførte at disse hadde den nødvendige kompetanse på sikkerhets- og terrorberedskap. Klassifikasjonsselskaper er privateide, profittorienterte organisasjoner som markedsfører seg som beskyttere, samtidig som de har tatt mål av seg til å være de fremste leverandører av forskrifter til ISPS-koden, derfor bør også habilitetsspørsmålet avklares. Ifølge informanter kom ESA til at kontrollanten kunne komme til å føre kontroll med egne retningslinjer. På tidspunket for inspeksjonene var ikke kompetansen til de delegerte kontrollorganer verifisert og ble derfor betraktet som manglende etterlevelse av paragraf $4.5 \mathrm{i}$ vedlegg III i regulering 725/2004.

Private havner og havneterminaler skal ha godkjent plan for sikkerhets- og terrorberedskap. Sikkerhetsplanen skal godkjennes av myndighetene. Godkjenning vil først kunne skje etter at kontrollmyndigheten har verifisert havneterminalen ved fysisk besøk og påsett at tiltak, rutiner og prosedyrer er etablert. Videre avdekket ESAs inspeksjoner at norske myndigheter heller ikke hadde sørget for å kommunisere til havne- og terminaleiere at det skal framgå av sikkerhetsplanen for havneinstallasjoner at det foreligger krav om Declaration of Security (DoS) før skip kan anløpe havn. Disse forhold ble av ESA vurdert som manglende samsvar med reguleringen.

I likhet med andre oppgaver som involverer to eller flere parter, ville maritim sikkerhets- og terrorberedskap vært mindre vanskelig dersom partene forsto hva den andre har til hensikt å forta seg. Måten å oppnå dette i den maritime sektor, under både ISPS-koden og nasjonal lovgivning, er ved hjelp av DoS. Declaration of Security definers i SOLAS konvensjonen som: "an agreement reached between a ship and either a port facility or another ship with which it interfaces, specifying the security measures each will implement«.

Fornuftig bruk av DoS er viktig, ikke bare som et instrument for å koordinere arbeidet med sikkerhets- og terrorberedskap mellom skip og havnefasiliteter, men også som en metode for å dokumentere forsvarlig implementering av ISPS-koden og andre relevante, maritime sikkerhetskrav. Dette blir særlig viktig når et skip skal anløpe en havn som ikke helt etterlever bestemmelsene i EU direktiv 725/2004 og ISPS-koden, eller har en tilfredsstillende sikkerhetsplan. 


\section{Holdninger og sikkerhetskultur}

Særlig når det gjaldt havnenes planverk, fysiske og tekniske sikringstiltak var noen informanter av den mening at det ikke sto så dårlig til i norske haver og havneanlegg som enkelte skulle ha det til. Kravene til planverk var i det vesentlige oppfylt da inspeksjonene fant sted og de fysiske og tekniske forutsetningene var imøtekommet. Likevel, ESA dokumenterte alvorlig svikt på flere områder som for eksempel i adgangskontroll og overvåkning i havnene. Derved åpner det seg adgang for uvedkommende til godset som ble oppbevart $\mathrm{i}$ havnen. Opplæring og øvelse av personell som en viktig del av sikringstiltakene $\mathrm{i}$ havner var ikke i overensstemmelse med reguleringene. Det ble også påvist at holdninger til sikkerhet var svakt utviklet $\mathrm{i}$ besetningene om bord på skip og ansatte $\mathrm{i}$ havnene, noe som kan ha sin årsak i at sikkerhetskultur ikke har den plass i disse næringene som er nødvendig for å oppnå tilfredsstillende sikkerhets- og terrorberedskap.

Holdninger kan endres og sikkerhetskultur kan bygges. Observasjoner i havner og på terminaler viser at det også i dag forekommer avvik som har fellestrekk med ESAs funn i 2008-2009. Særlig er det forholdet til mottak og levering av last, adgangskontroll og øvelser av personell. Representanter for havneadministrasjoner i flere av de havnene som ble inspisert av ESA, hevder at det arbeides kontinuerlig med opplæring som tar sikte på å informere om betydningen av en sikkerhetskultur. På terminaler i de samme havnene blir det vist til etablering av systemer og rutiner for å hindre at det oppstår avvik.

Kystverket følger opp kontrollen med både forhåndsanmeldte revisjoner av ISPS-godkjente havneterminaler og uanmeldte inspeksjoner. Interesseorganisasjonen som organiserer havner bidrar også med informasjon til sine medlemmer om betydningen av holdningsendring og sikkerhetskultur. Informasjon fra myndighetene tyder på at det tas sikte på å holde oppmerksomheten rettet mot prosesser som har som formål å endre holdninger og sikkerhetskultur.

\section{EUs sanksjonsmuligheter}

Hvilke sanksjonsmuligheter har EU overfor EØS-stater som ikke etterlever reguleringene? Ved mangler og avvik som ikke innen fastsatte frister blir rettet opp kan formelle sanksjoner iverksettes med hjemmel i EU-forordning 320/2008 jf. Artikkel 16. Denne inspeksjonsforordningen innebærer at ESA vil kunne informer alle EU- og EØS-stater om at sikkerhetsnivået i norske haver er så lavt at det kan utgjøre en fare for den generelle sikkerheten i hele Europa. Konsekvensen kan bli at skip som har anløpt norsk havn kan få problemer med å anløpe andre europeiske havner. For Norge som kyststat kan det medføre at skip i internasjonal fart vil vurdere ikke å anløpe norske havner. 


\section{Avslutning}

De formene for statens avvik og manglende etterlevelse av konvensjoner og avtaler og private selskapers lovbrudd som det er redegjort for ovenfor har sin bakgrunn i symbiosen offentlig-privat samarbeid og henger sammen med relasjonene til staten og den politikk som føres og praksis i selskaper i næringslivet. For å være i stand til å drive forretningsmessig, krever et moderne selskap rettslige rammer som gir oversikt over hvilke utnyttelsesmuligheter et marked gir. Infrastrukturen som skal til er det staten som utstyrer selskapene med for det marked som er aktuelt, og sammenhengen er ufravikelig mellom den politiske og forretningsmessige interessen. Alle stater er avhengige av næringsvirksomhet for å oppnå et økonomisk grunnlag for å føre det enkelte regimes politikk. Uten en politikk som støtter opp om økonomisk aktivitet vil næringslivet ikke være lønnsomt nok til å framskaffe de økonomiske resultat som staten etterspør. Som i denne sakstudien vil denne symbiosen kunne gi muligheter for manglende etterlevelse i det offentlige kontrollsystemet og for lovbrudd i private selskaper.

Norske myndigheter er gjennom konvensjoner og avtaler forpliktet til å oppfylle internasjonale krav med hensyn til forebygging av terroristangrep, både til sjøs og i havnene. Dette ansvar tar politiske myndighet på alvor. Et avansert system er implementert og består av en rekke lover og regler som tar sikte på kontroll av all identifiserbar risiko. Kontrolloppgavene er delegert til etater som har samfunnssikkerhet og beredskap som sitt ansvar. Når oppfølgingen i disse etatene forsinkes eller uteblir, oppstår det en situasjon som fra næringslivets side kan se ut som en mulighet til økt inntjeningen ved å unnlate å iverksette tiltak pålagt gjennom lovgivningen.

Terrortrusselen er et faktisk forhold som gjelder alle samfunn. Derfor ønsker norske myndigheter som en del av det internasjonale samarbeidet å forbedre den totale beskyttelsen mot terrorangrep. Den senere tids forslag dreier seg om å bygge sikkerheten videre ut for derved å styrke beredskapen i logistikkjeden som en viktig del av forberedelser, sending av last og lagring av gods som mottas for videre transport sjøveien.

Fysisk beredskap kan raskt settes i verk, men det tar lang tid å endre holdninger og bygge sikkerhetskulturer. I dag lever vi i en verden med trusler om terror. En konsekvens for vårt samfunn er at mange føler utrygghet, som igjen kan gi konsesjon til myndigheter om økt kontroll. Nøkkelen til beskyttelse mot denne fare ligger i tilrettelegging og gjennomføring av formålstjenlige preventive tiltak og kontinuerlig tilpasning av vår organisering. Dette vil kunne bidra til å sikre vår økonomiske effektivitet og respekten for de demokratiske prinsippene i vårt samfunn. 


\section{Noter}

1. Jan Georg Christophersen (Dr. philos) criminology is retire from a position as adviser in the Ministry of Justice and Public Security (Norway) The Norwegian National Crime Prevention Council.

2. "Security« defineres i dette arbeidet som »sikkerhet mot uønskede hendelser som resultat av overlegg og planlegging. Til forskjell fra »safety« som viser til en situasjon hvor man skal beskyttes mot fysisk, sosiale, finansielle, politiske, yrkesmessige og andre skader, ved feil og farlige hendelser eller skade som kan ses som uønsket. På norsk oppstår det et problem når det gjelder bruken av ordet security fordi vi anvender betegnelsen sikkerhet som synonym for både safety og security. I Lov-2007-02-16-9 Skipssikkerhetsloven kap. $6 \S 39$ benytter man »sikkerhets- og terrorberedskap«, mot at i Lov-1996-11-29-72 Petroleumsloven brukes »sikkerhet«. I dette arbeidet benyttes skipssikkerhetslovens formulering.

3. Tre faktorer vanskeliggjør definisjonsspørsmålet. For det første, den juridiske situasjon at staten utformer lovgivningen den selv skal kontrollere. For det andre, velger man derimot et utvidet sosiologisk perspektiv eksempelvis »organisasjonsmessig avvik« møter man statens skadepotensial, ikke nødvendigvis i form av lovbrudd, men som klanderverdige handlinger. Analysen blir derved mindre klar. Et tredje definisjonsmessig alternativ kan være at utfallet av handlingen, den forvoldte skade, legges til grunn. Derved oppnås større avstand til statens interesser og kontrollsystemer. Vanskeligheten med denne tilnærmingen er den definisjonsmessige avklaring av skadebegrepet og forankring av begrepet state-corporate crime i tradisjonell kriminologi (Bruce \& Backer, 2006; Kramer \& Michalowski, 1990; Kramer, Michalowski \& Kauzlarich, 2002; Kramer \& Michalowski, 2006; Michalowski \& Kramer, 2006; Michalowski \& Kramer, 2007; Friedrichs, 2010).

4. www.eftasurv.int

5. Avtalen mellom EFTA-staten om opprettelsen av et overvåkningsorgan ESA og domstolen (ODA), er inntatt i Norges Lover (etter hoveddelen av EØS-avtalen). Se St.prp. nr. 101 (1991-92, særlig s. 16-24.

6. Declaration of Security (DoS) er definert i Safety of Life at Sea (SOLAS) konvensjonen som: "an agreement reached between a ship and either a port facility or another ship with which it interfaces, specifying the security measures each will implement.«

7. Politiets sikkerhetstjeneste (PST) er en nasjonal politienhet og Norges sikkerhetstjeneste, direkte underlagt Justis- og beredskapsdepartementet og likestilt med Politidirektoratet.

8. Etterretningstjenesten også kalt E-tjenesten er sivil og militær utenlandsetterretningstjeneste og har et koordinerende og rådgivendeansvar for etterretningsvirksomheten i Forsvaret.

9. Meldingstjenesten SafeSeaNet Norway (SSNN) er et nasjonalt meldingssystem for skip som ankommer eller forlater norske havner. Systemet er basert på det europeiske Single Window konseptet som anbefaler at det utvikles nasjonale portaler for fartøyer, eierselskaper og operatører som kan sende inn rapporteringspliktig informasjon til nasjonale myndigheter (jf. EC direktiv 2002/59). Det norske systemet var i drift i 2005. Systemet drives og utvikles av Kystverket. 


\section{Referanser}

Aulette, J.R. \& Michalowski, R. (1993) Fire in Hamlet: a Case Study of State-Corporate Crime. In Political Crime in Contemporary America: a Critical Approach, (ed. Tunnell, K.) New York: Garland (pp.171-206).

Barak, G. (1991) Crime by the Capitalist State. Albany: SUNY

Bruce, A. and Becker, P. (2006) State-Corporate Crime and the Paducan Gaseous Diffusion Plant. Western Criminology Review, 8(2): 29-43.

Chambliss, W. (1989) State-organized crime. Chriminology, 27(2), 183-208.

Chambliss, W., Michalowski, R. \& Kramer, R.C. (eds.) (2010) State Crime in the Global Age. Portland Oregon: Willan Publishing.

Cohen, S. (2002) Human Rights and Crime of the State: The Culture of Denial. In Chriminological Perspectives, 2 nd Edition. (MeLaughlin, J., Muncie, J, \& Hughes, G. eds.) London: Sage.

Christophersen, J.G. (2009) Sikkerhetsstyring i skipsfarten 1998-2008: Bakgrunnsfaktorer for reguleringsmessig etterlevelse og overtredesle av ISM-koden. Diss., Universitetet i Oslo. Oslo: Unipub AS

Eskeland, S. (2011) De mest alvorlige forbrytelser. Oslo: Cappelen Damm AS.

Friedrichs, D. (2010) Trusted criminals: White Collar Crime in Contemporary Society, $4^{\text {th }}$ edn. Belmont, CA: Wadsworth.

Green, P. \& Ward, T. (2004) State Crime: Governments, Violence and Corruption. London: Pluto Press.

Kramer, R., \& Michalowski, R. (1990) Toward an Integrated Theory of State and Corporate Crime, paper presented at the $42^{\text {nd }}$ Annual Meeting of the American Society of Criminology, 9 November, Baltimore, Maryland.

Kramer, R. (1990) From White-Collar to Sate-Corporate Crime. Conference Paper. North Central Sociological Association, Louisvill, Kentucky, 22 March.

Kramer, R. \& Michalowski, R. (1991) State-Corporate Crime, prepared for American Society of Criminology Meeting, Baltimore, Maryland, 7-12 November 1990.

Kramer, R. (1992) The Space Shuttle Challenger Explosion: A Case Study of State-Corporate Crime. In White-Collar Crime Reconsidered, (eds. Schleger, K. \& Weisburd, D.). Boston: Northeastern University Press (pp.214-243).

Kramer, R.C., Michalowski, R.J. and Kauzlarich, D. (2002) The Origins and Development of the Concept and Theory of State-Corporate Crime. Crime \& Delinquency, 48(2), 263-282.

Kramer, R., \& Michalowski, R. (2006) The Original Formulation. In Michalowski, R. and

Kramer, R (eds.) State-Corporate Crime: Wrongdoing at the Intersection of Business and Government. New Brunswick, NJ: Rutgers University Press (pp. 18-26).

Matthews, R., \& Kauzlarich, D. (2000) The Crash of Valujet flight 592: A Case Study in StateCorporate Crime. Sociological Focus, 3(3): 281-98.

Michalowski, R and Kramer, R. (2006) State-Corporate Crime: Wrongdoing at the Intersection of Business and Government. New Brunswick, NJ: Rutgers University Press.

Michalowski, R. and Kramer, R. (2007) State-Corporate Crime and Criminological Inquiry. In Pontell, H. and Geis, G. (eds.) International Handbook of White-Collar and Corporate Crime. New York: Springer (pp. 200-19).

NOU 2012:2 Utenfor og innenfor. Norges avtaler med EU. Oslo: Utenriksdepartementet. 
NOU 2012:14 Rapport fra 22.juli-kommisjonen. Oslo: Statsministerens kontor.

Ross, J.I. (ed.) (2000) Varieties of State Crime and Its Control. Monseny, NY: Criminal Justice Press.

St.meld.nr. 22 (2007-2008) Samfunnssikkerhet - Samvirke og samordning. Oslo: Justis- og politidepartementet.

Whyte, D. (2003) Lethal regulation: state-corporate crime and the United Kingdom governement's new mercenaries. Journal of Law and Society vol. 30 issue 4 pp. 575-600. 